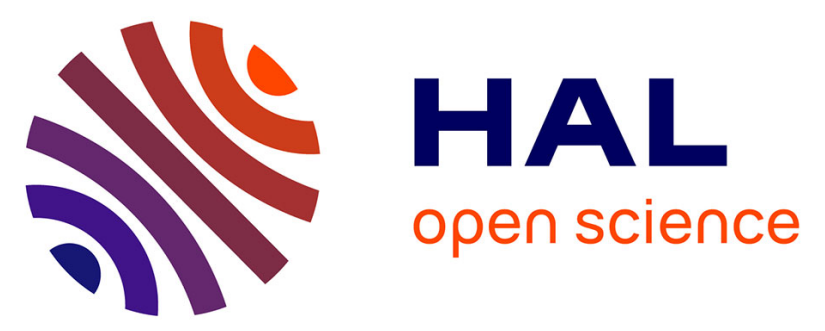

\title{
Gadonanotubes as Ultrasensitive pH-Smart Probes for Magnetic Resonance Imaging
}

\author{
Keith B. Hartman, Sabrina Laus, Robert D. Bolskar, Raja Muthupillai, \\ Lothar Helm, Éva Tóth, Andre E. Merbach, Lon J. Wilson
}

\section{To cite this version:}

Keith B. Hartman, Sabrina Laus, Robert D. Bolskar, Raja Muthupillai, Lothar Helm, et al.. Gadonanotubes as Ultrasensitive pH-Smart Probes for Magnetic Resonance Imaging. Nano Letters, 2008, 8 (2), pp.415-419. 10.1021/nl0720408 . hal-00283333

\section{HAL Id: hal-00283333 \\ https://hal.science/hal-00283333}

Submitted on 29 Sep 2021

HAL is a multi-disciplinary open access archive for the deposit and dissemination of scientific research documents, whether they are published or not. The documents may come from teaching and research institutions in France or abroad, or from public or private research centers.
L'archive ouverte pluridisciplinaire HAL, est destinée au dépôt et à la diffusion de documents scientifiques de niveau recherche, publiés ou non, émanant des établissements d'enseignement et de recherche français ou étrangers, des laboratoires publics ou privés. 


\title{
Gadonanotubes as Ultrasensitive pH-Smart Probes for Magnetic Resonance Imaging
}

\author{
Keith B. Hartman, ${ }^{\dagger}$ Sabrina Laus, ${ }^{\ddagger}$ Robert D. Bolskar, ${ }^{\S}$ Raja Muthupillai,,$\|, \perp$ \\ Lothar Helm, ${ }^{\ddagger}$ Eva Toth,\# Andre E. Merbach, ${ }^{\ddagger}$ and Lon J. Wilson ${ }^{\star}, \dagger$ \\ Department of Chemistry, Smalley Institute for Nanoscale Science and Technology, \\ Center for Biological and Environmental Nanotechnology, Rice University, Houston, \\ Texas 77251-1892, Laboratoire de Chimie Inorganique et Bioinorganique, Ecole \\ Polytechnique Fédérale de Lausanne, EPFL-BCH, CH-1015 Lausanne, Switzerland, \\ TDA Research, Inc., 12345 West 52nd Avenue, Wheat Ridge, Colorado 80033, Philips \\ Medical Systems, Cleveland, Ohio, Department of Radiology, St. Luke's Episcopal \\ Hospital/Texas Heart Institute, and Department of Radiology, Baylor College of \\ Medicine, Houston, Texas, and Centre de Biophysique Moleculaire, CNRS, rue \\ Charles-Sadron, 45071, Orleans, Cedex 2, France
}

With their nanoscalar, superparamagnetic $\mathrm{Gd}^{3+}$-ion clusters $(1 \times 5 \mathrm{~nm})$ confined within ultrashort $(20-80 \mathrm{~nm})$ single-walled carbon nanotube capsules, gadonanotubes are high-performance $T_{1}$-weighted contrast agents for magnetic resonance imaging (MRI). At $1.5 \mathrm{~T}, 37{ }^{\circ} \mathrm{C}$, and $\mathrm{pH}$ 6.5 , the $r_{1}$ relaxivity (ca. $180 \mathrm{mM}^{-1} \mathrm{~s}^{-1}$ per Gd ${ }^{3+}$ ion) of gadonanotubes is 40 times greater than any current $\mathrm{Gd}^{3+}$ ion-based clinical agent. Herein, we report that gadonanotubes are also ultrasensitive $\mathrm{pH}-\mathrm{smart}$ probes with their $r_{1} / \mathrm{pH}$ response from $\mathrm{pH} 7.0-7.4$ being an order of magnitude greater than for any other MR contrast agent. This result suggests that gadonanotubes might be excellent candidates for the development of clinical agents for the early detection of cancer where the extracellular pH of tumors can drop to $\mathrm{pH}=7$ or below. In the present study, gadonanotubes have also been shown to maintain their integrity when challenged ex vivo by phosphate-buffered saline solution, serum, heat, and $\mathrm{pH}$ cycling.

Introduction. As diagnostic radiology strives for earlier detection of disease, the demand for greater contrast agent performance inevitably grows as well. For example, magnetic resonance imaging (MRI), a technique ideal for imaging soft tissue, now often includes the administration of chemical contrast agents (CAs) to enhance signal intensity. Current clinical CAs are small-molecule $\mathrm{Gd}^{3+}$ chelates that disseminate uniformly throughout the vasculature. They do not target specific areas or disease regions, nor do they respond to cellular stimuli, but rather they matriculate throughout the body, confined to the circulatory system, prior to eventual elimination. Only features with large volumes of blood flow can be differentiated in the MR image, thus, making the detection of metastatic cancer in its earliest stages, when tumors are only a few millimeters in size, nearly impossible.

\footnotetext{
* Corresponding author. E-mail: Durango@ rice.edu.

$\dagger$ Rice University.

Ecole Polytechnique Fédérale de Lausanne.

$\S$ TDA Research, Inc.

" Philips Medical Systems.

$\perp$ Baylor College of Medicine.

\# CNRS.
}

The rapidly emerging field of molecular imaging seeks to develop CAs as molecular probes that respond to cellular processes or cellular markers, contrary to the current clinical CAs that are essentially noninteracting bystanders during the imaging process. Some recent prototype MRI CAs have been designed to respond to $\mathrm{pH},{ }^{1-4} \mathrm{pO}_{2},{ }^{5,6}$ specific enzymes, ${ }^{7,8}$ or to metal ion concentration,,$^{9,10}$ while others have been molecularly targeted to an area of interest. ${ }^{11-13}$ Sensitivity toward $\mathrm{pH}$ is particularly attractive for a CA probe because a universal feature of cancerous tissues is that the $\mathrm{pH}$ of the diseased tissue is significantly lower than that of healthy tissue. While the normal physiological $\mathrm{pH}$ is 7.4, the extracellular $\mathrm{pH}$ of cancerous tissue is less than 7.0 and in certain cases as low as 6.3. ${ }^{14}$ The acidity of tumors is present from the onset of tumor growth as it is a consequence of elevated rates of glycolysis, and hence, greater production of lactic acid, ${ }^{15}$ making $\mathrm{pH}$ an ideal parameter for detecting early stage cancer. ${ }^{16,17}$ Current measurements of pathological $\mathrm{pH}$ typically involve magnetic resonance spectroscopy (chemical shift measurements) with ${ }^{31} \mathrm{P}$ or ${ }^{19} \mathrm{~F}$ probes. Measurements using ${ }^{31} \mathrm{P}$ present in endogenous phosphates is possible, ${ }^{18}$ 


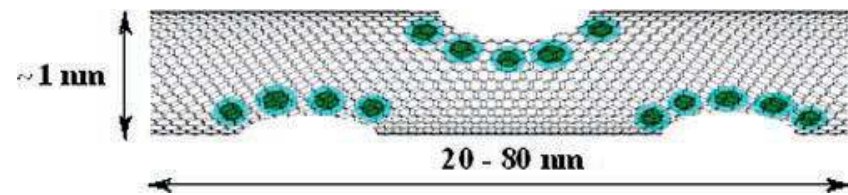

Figure 1. A pictorial representation of the gadonanotubes. Small, superparamagnetic clusters of $\mathrm{Gd}^{3+}$ ions reside within the sidewall defects of the nanotube (chloride counteranions omitted for clarity).

however a wide variety of external agents, often natural product derivatives, labeled with either ${ }^{31} \mathrm{P}$ or ${ }^{19} \mathrm{~F}$ can be attached to a CA whose NMR shift is sensitive to $\mathrm{pH} .{ }^{19-23}$ While these probes can be effective, ${ }^{1} \mathrm{H}$-based probes are preferred because they are intrinsically the most sensitive of MR-based probes.

We recently reported that an ultrashort carbon nanotubebased MRI CA, known as gadonanotubes, significantly outperform all known clinical MRI CAs. ${ }^{24,25}$ At a standard clinical field strength of ca. $1.5 \mathrm{~T}$, the gadonanotubes demonstrate a 40-fold increase in efficacy (relaxivity) compared to CAs in current clinical use. These gadonanotubes are 20-80 nm segments of single-walled, full-length carbon nanotubes that have been cut chemically via fluorination and pyrolysis into ultrashort tubes (US-tubes), followed by aqueous internal loading with $\mathrm{Gd}^{3+}$ ions. Because of the sidewall defects created in the US-tubes as a consequence of the chemical cutting procedure, the $\mathrm{Gd}^{3+}$ ions load and exist as small clusters (ca. $1 \times 5 \mathrm{~nm} ; 3-10 \mathrm{Gd}^{3+}$ ions per cluster) with chloride counter anions. ${ }^{24}$ Magnetic characterization of the gadonanotubes has revealed the clusters to be superparamagnetic, which is likely the cause of the extremely high $T_{1}$-weighted relaxivity. Because of this unprecedented relaxivity (ranging from ca. $180 \mathrm{mM}^{-1} \mathrm{~s}^{-1}$ at $1.5 \mathrm{~T}$ to $>600$ $\mathrm{mM}^{-1} \mathrm{~s}^{-1}$ at $0.2 \mathrm{mT}$, and $\mathrm{pH} 6.5$ ) and because the variablefield NMRD profile cannot be interpreted using current Solomon-Bloembergen-Morgan (SBM) theory, ${ }^{26}$ gadonanotubes are likely a bona fide example of special properties (magnetic/relaxivity) arising from the nanoscalar confinement of $\mathrm{Gd}^{3+}$-ion clusters within their carbon capsule sheaths. A depiction of the gadonanotube structure is shown in Figure 1. Herein, we report that the gadonanotubes also perform as ultrasensitive "smart" probes in the burgeoning field of nanotechnology-based medicine by exhibiting a dramatic response to $\mathrm{pH}$ and thermal change under physiologically relevant conditions, where it has been demonstrated that the integrity of the gadonanotube is also maintained.

Results/Discussion. Relaxivities (per $\mathrm{Gd}^{3+}$ ion) of the surfactant-suspended gadonanotubes were acquired as a function of $\mathrm{pH}$ from 3 to 10 at $1.41 \mathrm{~T}$ and $37^{\circ} \mathrm{C}$ (Figure 2). The $r_{1}$ versus $\mathrm{pH}$ curve was found to be fully reversible upon $\mathrm{pH}$ cycling. As seen from the figure, the relaxivity of the gadonanotubes undergoes more than a 3 -fold increase in relaxivity from $\mathrm{pH}=8.3\left(40 \mathrm{mM}^{-1} \mathrm{~s}^{-1}\right)$ to $\mathrm{pH}=6.7(133$ $\mathrm{mM}^{-1} \mathrm{~s}^{-1}$ ) at $37^{\circ} \mathrm{C}$ with the slope of the change between $\mathrm{pH} 7.4$ and 7.0 being $98 \mathrm{mM}^{-1} \mathrm{~s}^{-1} / \mathrm{pH}$. No other $\mathrm{pH}-$ responsive MRI CA has demonstrated such a dramatically large change in relaxivity over such a narrow $\mathrm{pH}$ range. For example, a pH-responsive agent described by Woods et al. utilized a $\mathrm{pH}$-respondant pendant arm that ligates $\mathrm{Gd}^{3+}$ ion at high $\mathrm{pH}$ and releases it at low $\mathrm{pH}$ and undergoes a $60 \%$

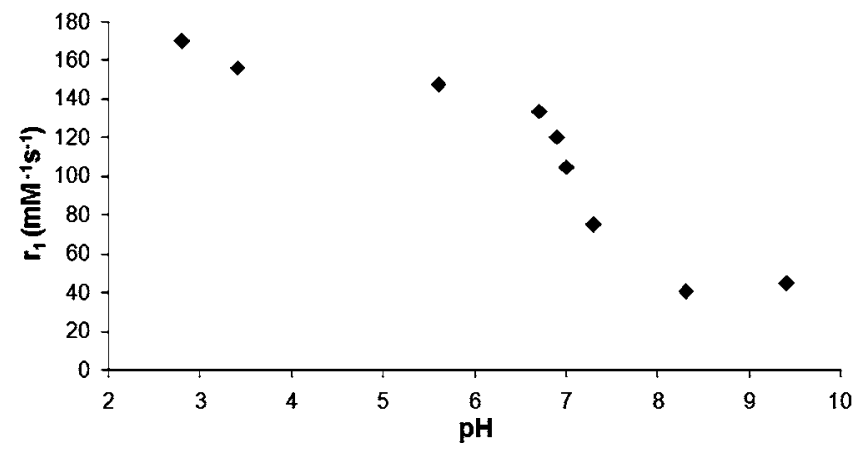

Figure 2. $r_{1}$ relaxivity (per $\mathrm{Gd}^{3+}$ ion) as a function of $\mathrm{pH}$ for the gadonanotubes at $1.41 \mathrm{~T}$ and $37^{\circ} \mathrm{C}$.

increase in relaxivity over $\mathrm{pH}$ ranges of $4.4 \mathrm{mM}^{-1} \mathrm{~s}^{-1}$ at $\mathrm{pH}$ 8.5 to $7 \mathrm{mM}^{-1} \mathrm{~s}^{-1}$ at $\mathrm{pH} 6.5$ (slope $\left.=1.3 \mathrm{mM}^{-1} \mathrm{~s}^{-1} / \mathrm{pH}\right){ }^{1}$ $\mathrm{A} \mathrm{Gd}^{3+}-\mathrm{DO} 3 \mathrm{~A}$ tetrapod system detailed by Jebasingh and Alexander exhibited a near doubling of relaxivity from 3.2 $\mathrm{mM}^{-1} \mathrm{~s}^{-1}$ at $\mathrm{pH} 8.5$ to $6 \mathrm{mM}^{-1} \mathrm{~s}^{-1}$ at $\mathrm{pH} 6.5$ (slope $=1.4$ $\left.\mathrm{mM}^{-1} \mathrm{~s}^{-1} / \mathrm{pH}\right){ }^{4}$ Another example, a PAMAM dendrimerbased system, has demonstrated an approximate $20 \%$ increase in relaxivity over similar $r_{1} / \mathrm{pH}$ ranges (slope $=4.4 \mathrm{mM}^{-1}$ $\mathrm{s}^{-1} / \mathrm{pH}$ ). ${ }^{27}$ Finally, a few $\mathrm{Gd} @ \mathrm{C}_{60}$-based CAs (gadofullerenes) also exhibit $r_{1} / \mathrm{pH}$ variation that is strongly aggregation state dependent (slope $<10 \mathrm{mM}^{-1} \mathrm{~s}^{-1} / \mathrm{pH}$ ). ${ }^{28-30}$ Thus, the gadonanotubes are interesting materials for MRI CA development, not only because they possess the greatest efficacy (relaxivity) by far at clinical fields of any known $\mathrm{CA}$, but also because of their dramatic response to $\mathrm{pH}$ around physiological $\mathrm{pH}$.

While the aforementioned relaxivity measurements are the accepted standard by which CAs are compared, relaxivity measurements do not guarantee that agents will perform accordingly in an MRI scanner. To confirm its $\mathrm{pH}$-dependent properties in an MRI scanner, a sample of gadonanotubes was divided into two parts, in which one part was adjusted to a $\mathrm{pH}$ of 7.0 and a second to a $\mathrm{pH}$ of 7.4. The $\mathrm{pH}$ was measured both before and after the MRI scan and found to be unchanged. A $T_{1}$-weighted inversion-recovery scan was collected on the two samples using a 1.5 T Philips MR scanner, which confirmed a large relaxivity difference between the two samples (Figure 3). The image in Figure 3 shows the significant difference in the relaxivity of the two samples, which differed by a mere $0.4 \mathrm{pH}$ units. The relaxivities from the images were calculated to be $200 \mathrm{mM}^{-1}$ $\mathrm{s}^{-1}\left(\mathrm{pH} \mathrm{7.0)}\right.$ and $98 \mathrm{mM}^{-1} \mathrm{~s}^{-1}(\mathrm{pH} 7.4)$ at $25^{\circ} \mathrm{C}$.

Dynamic light scattering (DLS) data provided evidence that aggregation of the gadonanotubes does not play a major role in their high-performance relaxivity characteristics. Previous studies on some related carbon nanostructure-based MRI CAs, the Gd@ $\mathrm{C}_{60} \mathrm{CAs}$ (gadofullerenes), also found relaxivities that were both $\mathrm{pH}$ and aggregation state dependent. ${ }^{28-30}$ For example, gadofullerene aggregates range in size from $50 \mathrm{~nm}$ at $\mathrm{pH}=9$ to $1200 \mathrm{~nm}$ at $\mathrm{pH}=4$, with relaxivities of $75 \mathrm{mM}^{-1} \mathrm{~s}^{-1}$ at $\mathrm{pH} \approx 4$ and $39 \mathrm{mM}^{-1} \mathrm{~s}^{-1}$ at $\mathrm{pH} \approx 10$. Thus, it was first assumed that gadonanotubes would also exhibit a similar aggregation state behavior and that this would be related to their $\mathrm{pH}$-dependent relaxivities. However, the DLS data (Figure 4) clearly demonstrates that the aggregation state behavior of the gadonanotubes is vastly 


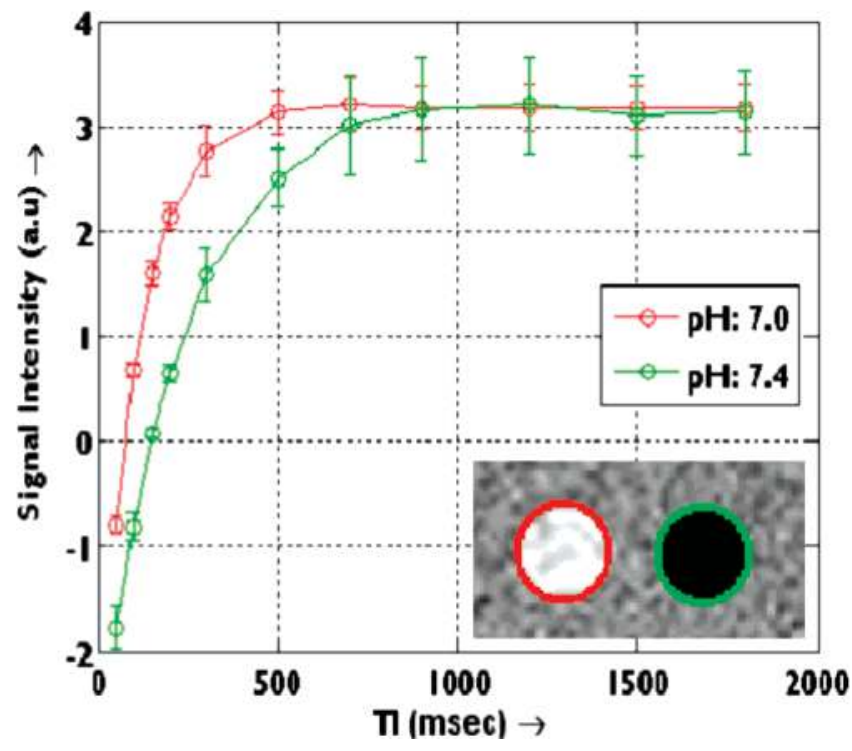

Figure 3. An inversion-recovery scan at a $150 \mathrm{~ms}$ time slice of the gadonanotubes at $\mathrm{pH} 7.0$ (inset, left) and $\mathrm{pH} 7.4$ (inset, right) at $1.5 \mathrm{~T}$ and $25^{\circ} \mathrm{C} ; T_{1}=110 \mathrm{~ms}$ at $\mathrm{pH}=7.0$ and $T_{1}=219 \mathrm{~ms}$ at $\mathrm{pH}=7.4$. The circles around the inset slices are not analyzed regions of interest, but are present only to indicate coordination with the proper relaxivity fit.

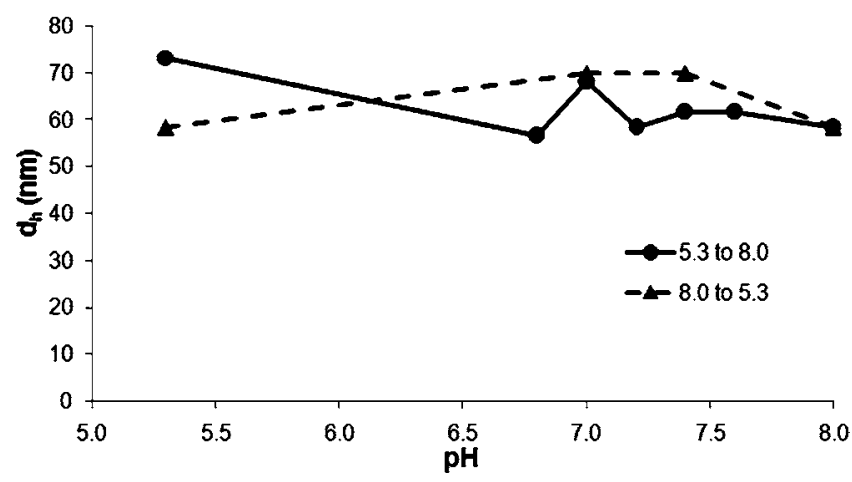

Figure 4. The number distribution of particle size of the gadonanotubes as a function of $\mathrm{pH}$ as determined by DLS. The samples were cycled from $\mathrm{pH} 5.3$ up to 8.0 and then back down to 7.4, 7.0, and 5.3. Although there appears to be some small variation in particle size, this variation is likely insignificant because by comparison gadofullerene particles undergo a 20 -fold increase in aggregate size with decreasing $\mathrm{pH} .{ }^{28}$

different than that for gadofullerenes and is unlikely to contribute to the observed relaxivity properties.

An alternative explanation of the $\mathrm{pH}$-relaxivity relationship is that alteration of the $\mathrm{pH}$ results in $\mathrm{Gd}^{3+}$-ion loss from the gadonanotubes upon exposure to alkaline solutions. Because the superparamagnetic clusters are believed to be a key to the high-performance characteristics of these probes, the integrity of these $\mathrm{Gd}^{3+}$-ion clusters and their retention of $\mathrm{Gd}^{3+}$ are of utmost importance. Several experiments were conducted to test gadonanotube integrity as a function of $\mathrm{pH}$, and the scope of the experiment was eventually widened to test not only $\mathrm{pH}$, but to also different physiological challenges, including phosphate-buffered saline solution (PBS), bovine serum, and heat. In an additional set of experiments, a sample of gadonanotubes was membrane dialyzed in PBS solution for $48 \mathrm{~h}$ with samples periodically taken for $\mathrm{Gd}^{3+}$.

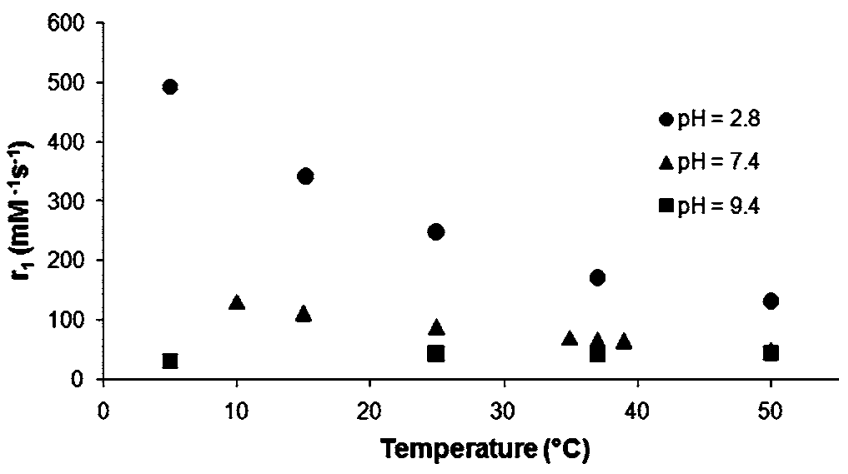

Figure 5. $r_{1}$ relaxivity (per $\mathrm{Gd}^{3+}$ ion) at $1.41 \mathrm{~T}$ as a function of temperature for the gadonanotubes.

ion analysis. None of these trials resulted in a measurable loss of $\mathrm{Gd}^{3+}$ ion as determined by inductively coupled plasma-atomic emission spectroscopy (ICP-AES). Furthermore, there was no adverse affect on gadonanotube relaxivity after dialysis. The dialysis experiments confirmed that the $\mathrm{Gd}^{3+}$-ion clusters are stable with regard to physiological conditions, and that $\mathrm{Gd}^{3+}$ ion is not leaked from the gadonanotube itself. The limit of detection for ICP-AE instrumentation is ca. $2 \mathrm{ppb}$, which is less than $1 \%$ of the total $\mathrm{Gd}^{3+}$-ion concentration present in a gadonanotube sample. Thus, the gadonanotubes retained greater than $99 \%$ of their $\mathrm{Gd}^{3+}$-ion concentration upon exposure to the $\mathrm{pH}$ and temperature challenges, as well as to the physiological condition challenge as mimicked by PBS dialysis. Taken together with the DLS results, the physiological challenge data indicate that the high-relaxivity property of the gadonanotubes is not due to an aggregation phenomenon nor are $\mathrm{Gd}^{3+}$ ions released from the gadonanotubes during $\mathrm{pH}$ cycling because the $\mathrm{pH}$-dependent relaxivities of Figure 2 are reproduced exactly upon repeated cycling.

Perhaps the most intriguing piece of data is the variabletemperature relaxivity study shown in Figure 5. To investigate the temperature dependence of the water exchange rate (assuming access to $\mathrm{Gd}^{3+}$ ions by water), a temperaturerelaxivity study was performed on three gadonanotube samples with one sample under acidic conditions $(\mathrm{pH}=2.8)$, a second sample under basic conditions $(\mathrm{pH}=9.4)$, and a third sample at physiological conditions $(\mathrm{pH}=7.4)$ at $1.41 \mathrm{~T}$. The results of the study are shown in Figure 5. This plot of relaxivity versus temperature demonstrated that the relaxivity is independent of temperature under basic conditions, whereas under acidic conditions the relaxivity rose dramatically to ca. $500 \mathrm{mM}^{-1} \mathrm{~s}^{-1}$ as the temperature was lowered from 50 to $5{ }^{\circ} \mathrm{C}$. The general shape of the $\mathrm{pH} 2.8$ curve in Figure 5 has been previously documented for a $\mathrm{Gd}^{3+}$ chelate attached to a large protein where the relaxivity nearly tripled from $3.2^{1}$ to $8.2 \mathrm{mM}^{-1} \mathrm{~s}^{-1}$ over the same temperature range. ${ }^{31}$ There are two possible explanations for the strong increase of relaxivity at $\mathrm{pH} 2.8$ by lowering temperature: (i) A formation of larger aggregates leading to slower rotational motion or (ii) slowing down of proton exchange. If we assume that the high relaxivity observed with gadonanotubes is due to high mobility of water protons, a property known from several studies, ${ }^{32,33}$ we can speculate that relaxivity is limited at high temperatures by too fast of proton exchange 
and that the lowering of temperature would therefore lead to an increase in $r_{1}$. Because of the failure of the gadonanotubes NMRD profile to be fit by SBM theory, any attempt to further explain the $\mathrm{pH}$ phenomenon is only conjecture at this point.

Clearly gadonanotubes are intriguing building-block materials for the development of clinical MRI CAs, not only because of their unparalleled high relaxivities, but also because of their exceptional pH-dependency. Although the relaxivity of gadonanotubes exhibits an impressive thermal response, it is unlikely to be of practical use in medicine or biology because the relaxivity change is relatively small over the narrow range of temperatures found in biology. In contrast, because of the sharp and dramatic change in relaxivity over physiologically relevant $\mathrm{pH}$ ranges, the gadonanotubes make compelling agents for the development of $\mathrm{pH}$ sensitive MRI probes. With their high relaxivity alone, the gadonanotubes make for an attractive circulatory CA candidate, especially in attempts to diagnose areas of cellular stress such as cancer or ischemia. Because of the ultrasensitivity of these agents to minute $\mathrm{pH}$ change, they also might lend themselves to a variety of other physiological applications that depend upon tight $\mathrm{pH}$ regulation, including certain enzymes that operate within narrow $\mathrm{pH}$ ranges ${ }^{34,35}$ or processes involving heart mechanics. ${ }^{36,37}$

Methods. The gadonanotube samples were prepared and characterized as previously described. ${ }^{24}$ Relaxivities (per $\mathrm{Gd}^{3+}$ ion) of surfactant-suspended (sodium dodecyl benzene sulfonate) gadonanotubes were acquired as a function of $\mathrm{pH}$ from 3 to 10 at $1.41 \mathrm{~T}$ and $37^{\circ} \mathrm{C}$ (Figure 2) using a Bruker mq60 MiniSpec. $T_{1}$ values of the empty US-tubes are ca. $2500 \mathrm{~ms}$ (the $T_{1}$ values of the gadonanotubes are 100-250 $\mathrm{ms}$ ), and previous SQUID analysis has demonstrated that the empty US-tubes do not demonstrate any observable magnetization, ${ }^{24}$ indicating that the magnetic properties of the gadonanotubes can be attributed to the $\mathrm{Gd}^{3+}$-ion clusters. $\mathrm{pH}$ was altered using ca. $0.001-0.01 \mu \mathrm{L}$ amounts of $1 \mathrm{M}$ $\mathrm{LiOH}$ and $\mathrm{HCl}$. The mass of the sample was measured after addition of each acid or base and was less than $0.01 \mathrm{mg}$, so that $\mathrm{Gd}^{3+}$-ion concentration change was negligible. Although, the magnitude of the relaxivity change can vary somewhat between different batches of gadonanotube preparations, samples other than the one in Figure 2 have demonstrated at least a $25 \%$ increase in relaxivity from $\mathrm{pH} 7.4$ to 7.0 with the greatest being a $100 \%$ increase (a 300\% increase from $\mathrm{pH} 8.3$ to $\mathrm{pH} 6.9$ ).

DLS measurements were collected using a Nanotrac Ultra DLS Nanoparticle Analyzer (Microtrac, Inc) as a function of $\mathrm{pH}$. In the DLS experiment, $\mathrm{pH}$ was adjusted incrementally from 5.3 to 8.5 and then back down to $7.4,7.0$, and 5.3. Five measurements were taken at each point with the high and low measurements discarded, and an average of three measurements at each point was reported. The accuracy of the measurements was validated with a $20 \mathrm{~nm}$ polystyrene bead standard.

To test for physiological stability, samples of gadonanotubes were exposed to PBS, bovine serum, low $\mathrm{pH}(<2)$ or high $\mathrm{pH}(>12)$, all of which were at a temperature of 40 ${ }^{\circ} \mathrm{C}$. In a typical experiment, $3 \mathrm{mg}$ of gadonanotubes were challenged for $1 \mathrm{~h}$ with bath ultrasonication. Samples were then filtered through a 0.22 micron syringe filter and the filtrate was collected for ICP-AES analysis on a Perkin-Elmer Optima 4300 DV instrument. None of these trials resulted in a measurable loss of $\mathrm{Gd}^{3+}$ ion. In a similar set of experiments, a sample of gadonanotubes was membrane dialyzed in PBS solution for $48 \mathrm{~h}$ with periodic samples taken for $\mathrm{Gd}^{3+}$-ion analysis. Again, no $\mathrm{Gd}^{3+}$ ion was detectable by ICP-AE for any of the aliquots. Furthermore, there was no adverse affect on gadonanotube relaxivity after dialysis.

The variable-temperature study on the gadonanotubes at $1.41 \mathrm{~T}$ was performed by dividing the sample into two parts with one sample under acidic conditions $(\mathrm{pH}=2.8)$ and the other sample under basic conditions $(\mathrm{pH}=9.4)$. Another separate sample was set to physiological conditions ( $\mathrm{pH}$ 7.4). The temperature was controlled using a water bath by pumping a thermostated ethanol-water mixture through the MiniSpec probe.

To confirm its $\mathrm{pH}$-dependent properties with an MRI scanner, a sample of gadonanotubes was divided into two parts with one sample adjusted to a $\mathrm{pH}$ of 7.0 and a second sample adjusted to a $\mathrm{pH}$ of 7.4. Samples were imaged simultaneously in $7.5 \mathrm{~mm}$ quartz NMR tubes with each sample containing on the order of $10^{16}$ nanotubes and with each nanotube containing approximately $100 \mathrm{Gd}^{3+}$ ions. The $\mathrm{pH}$ was measured both before and after the MRI scans and was found to be unchanged. A clinical whole-body $1.5 \mathrm{~T}$ Philips MR imager was used for MR imaging. A quadrature head coil was used for signal reception. To minimize partial volume effects, we obtained a high-resolution $T_{1}$ map of the phantoms by using an inversion-recovery-prepared spin echo technique with the following acquisition parameters: TR/TE, 4000/15 ms; acquired voxel size, $0.5 \times 0.5 \times 3.0$ $\mathrm{mm}^{3}$; and reconstructed voxel size, $0.25 \times 0.25 \times 3 \mathrm{~mm}^{3}$. These inversion recovery images were acquired at a series of inversion delays (TI) ranging from 50 to $1800 \mathrm{~ms}$. Circular regions-of-interest (ROI) were drawn on the images obtained at different $T_{1}$, and the mean and standard deviation of the signal intensities within the ROI were computed. A nonlinear, least-squares curve-fitting algorithm (Marquardt-Levenberg) was used to estimate the $T_{1}$ of the sample of interest.

Acknowledgment. We would like to acknowledge the following for support: U.S. National Institutes of Health Grant R21EB005390 (R.D.B./L.J.W.); Robert A. Welch Foundation Grant C-0627 (L.J.W.); the Center for Biological and Environmental Nanotechnology U.S. NSF EEC-0118007 (K.B.H.); the Swiss National Science Foundation and European funded EMIL program (S.L., L.H., and A.E.M.); finally K.B.H. gratefully acknowledges support by the Norman Hackerman Fellowship in Chemistry.

\section{References}

(1) Woods, M.; Kiefer, G. E.; Bott, S.; Castillo-Muzquiz, A.; Eshelbrenner, C.; Michaudet, L.; McMillan, K.; Mudigunda, S. D. K.; Ogrin, D.; Tircso, G.; Zhang, S.; Zhao, P.; Sherry, A. D. J. Am. Chem. Soc. 2004, 126 (30), 9248-9256.

(2) Zhang, S.; Wu, K.; Sherry, A. D. Angew. Chem., Int. Ed. 1999, 38 (21), 3192-3194.

(3) Lowe, M. P.; Parker, D.; Reany, O.; Aime, S.; Botta, M.; Castellano, G.; Gianolio, E.; Pagliarin, R. J. Am. Chem. Soc. 2001, 123 (31), $7601-7609$.

(4) Jebasingh, B.; Alexander, V. Inorg. Chem. 2005, 44 (25), 94349443. 
(5) Aime, S.; Botta, M.; Gianolio, E.; Terreno, E. Angew. Chem., Int. Ed. 2000, 39 (4), 747-750.

(6) Burai, L.; Toth, E.; Seibig, S.; Scopelliti, R.; Merbach, A. E. Chem.Eur. J. 2000, 6 (20), 3761-70.

(7) Allen, M. J.; Meade, T. J. J. Biol. Inorg. Chem. 2003, 8 (7), 746750 .

(8) Moats, R. A.; Fraser, S. E.; Meade, T. J. Angew. Chem., Int. Ed. 1997, 36 (7), 726-728.

(9) Hanaoka, K.; Kikuchi, K.; Urano, Y.; Narazaki, M.; Yokawa, T.; Sakamoto, S.; Yamaguchi, K.; Nagano, T. Chem. Biol. 2002, 9 (9), 1027-1032.

(10) Que, E. L.; Chang, C. J. J. Am. Chem. Soc. 2006, 128 (50), 1594215943.

(11) Anderson, S. A.; Rader, R. K.; Westlin, W. F.; Null, C.; Jackson, D.; Lanza, G. M.; Wickline, S. A.; Kotyk, J. J. Magn. Reson. Med. 2000, 44 (3), 433-9.

(12) Sipkins, D. A.; Cheresh, D. A.; Kazemi, M. R.; Nevin, L. M.; Bednarski, M. D.; Li, K. C. Nat. Med. 1998, 4 (5), 623-6.

(13) Tiefenauer, L. X.; Kuhne, G.; Andres, R. Y. Bioconj. Chem. 1993, 4 (5), 347-52.

(14) Gillies Robert, J.; Raghunand, N.; Garcia-Martin Maria, L.; Gatenby Robert, A. IEEE Eng. Med. Biol. 2004, 23 (5), 57-64.

(15) Simon, S. M. Drug Disc. Today 1999, 4 (1), 32-38.

(16) Tannock, I. F.; Rotin, D. Cancer Res. 1989, 49 (16), 4373-84.

(17) Stubbs, M.; McSheehy, P. M. J.; Griffiths, J. R.; Bashford, C. L. Mol. Med. Today 2000, 6 (1), 15-19.

(18) Stubbs, M.; Bhujwalla, Z. M.; Tozer, G. M.; Rodrigues, L. M.; Maxwell, R. J.; Morgan, R.; Howe, F. A.; Griffiths, J. R. NMR Biomed. 1992, 5 (6), 351-9.

(19) Gillies, R. J.; Liu, Z.; Bhujwalla, Z. Am. J. Physiol. 1994, 267 (1, Pt. 1), C195-C203.

(20) Mason, R. P. Curr. Med. Chem. 1999, 6 (6), 481-499.

(21) Deutsch, C. J.; Taylor, J. S. Biophys. J. 1989, 55 (4), 799-804.

(22) Deutsch, C.; Taylor, J. S.; Price, M. J. Cell Biol. 1984, 98 (3), 88593.
(23) Deutsch, C.; Taylor, J. S.; Wilson, D. F. Proc. Natl. Acad. Sci. U.S.A. 1982, 79 (24), 7944-8.

(24) Sitharaman, B.; Kissell, K. R.; Hartman, K. B.; Tran, L. A.; Baikalov, A.; Rusakova, I.; Sun, Y.; Khant, H. A.; Ludtke, S. J.; Chiu, W.; Laus, S.; Toth, E.; Helm, L.; Merbach, A. E.; Wilson, L. J. Chem. Commun. 2005 (31), 3915-3917.

(25) Sitharaman, B.; Wilson, L. J. Int. J. Nanomed. 2006, 1 (3), 291295.

(26) The Chemistry of Contrast Agents in Medical Magnetic Resonance Imaging; Merbach, A. E., Toth, E., Eds.; 2001; p 471.

(27) Laus, S.; Sour, A.; Ruloff, R.; Toth, E.; Merbach, A. E. Chem.Eur. J. 2005, 11 (10), 3064-3076.

(28) Laus, S.; Sitharaman, B.; Toth, E.; Bolskar, R. D.; Helm, L.; Asokan, S.; Wong, M. S.; Wilson, L. J.; Merbach, A. E. J. Am. Chem. Soc. 2005, 127 (26), 9368-9369.

(29) Sitharaman, B.; Bolskar, R. D.; Rusakova, I.; Wilson, L. J. Nano Lett. 2004, 4 (12), 2373-2378.

(30) Toth, E.; Bolskar, R. D.; Borel, A.; Gonzalez, G.; Helm, L.; Merbach, A. E.; Sitharaman, B.; Wilson, L. J. J. Am. Chem. Soc. 2005, 127 (2), 799-805.

(31) Cheng, T.-H.; Lee, W.-T.; Jeng, J.-S.; Wu, C.-M.; Liu, G.-C.; Chiang, M. Y. N.; Wang, Y.-M. Dalton Trans. 2006 (43), 5149-5155.

(32) Dellago, C.; Hummer, G. Phys. Rev. Lett. 2006, 97 (24), 245901/ $1-245901 / 4$

(33) Dellago, C.; Naor, M. M.; Hummer, G. Phys. Rev. Lett. 2003, 90 (10), 105902/1-105902/4

(34) Madshus, I. H. Biochem. J. 1988, 250 (1), 1-8.

(35) Davies, D. D. Symp. Soc. Exper. Biol. 1973, 27, 513-29.

(36) Vaughan-Jones, R. D.; Peercy, B. E.; Keener, J. P.; Spitzer, K. W. J. Physiol. 2002, 541 (1), 139-158.

(37) Bountra, C.; Vaughan-Jones, R. D. J. Physiol. 1989, 418, 163-87. 